\title{
Ілля Давіденко
}

\section{ТЕНДЕНЦІЇ СУЧАСНОГО ГЕГЕЛЕЗНАВСТВА.}

\section{Bykova, M., Westphal, K., et al. (2020). The Palgrave Hegel hand- book. Basingstoke: Palgrave Macmillan.}

2020 рік, ніби превентивно усуваючи будь-який сумнів щодо перспектив гегелезнавчих досліджень в нашій країні, містить деякі ознаки довгоочікуваного відродження інтересу української філософської спільноти до Гегелевого філософського доробку. Вихід друком кількох матеріалів і проведення декількох заходів (включно зі студентськими), присвячених Гегелевій філософії, переклад однієї з найвідоміших статей Гегеля, - усе це складає далеко не повний перелік минулорічних подій, що вселяють віру в майбутнє гегелезнавства в Україні. Можливо, наведений перелік подій є занадто коротким, щоб на його підставі говорити про доконане постання українського гегелезнавства, однак він свідчить, на мою думку, про певну готовність до перезаснування гегелезнавчого дискурсу й переважне звільнення спільноти від задавнених перверзій ${ }^{1}$ сприйняття Гегелевої філософії, зумовлених пануванням радянського марксизму в українському інтелектуальному середовищі. Нині ж, візьму на себе сміливість так стверджувати, принаймні символічні перепони на шляху нашого долучення до сучасного гегелезнавства вже не $є$ актуальними.

Тим часом, коли йтиметься про світове гегелезнавство, ми маємо визнати, що воно вже ввійшло в новий етап свого існування. Визначальною рисою цього етапу $є$, на нашу думку, остаточний вихід з функціонування переважно в окремих дослідницьких центрах (цю окремішність слід правильно розуміти, бо Захід ніколи не знав радянської автаркічності; ба навіть в СРСР рівень зовнішніх контактів, скажімо, московських і решти союзних дослідників був незіставний) і перевершення регіональних інтелектуальних і академічних контекстів. Підтвердженням цієї тези може бути збірка, узята нами до огляду, а саме «Посібник з Гегеля» ${ }^{2}$, що 2020 -го року вийшла друком у видавництві Palgrave Macmillan під редакцією Марини Бикової й Кенета Вестфала ${ }^{4}$.

(C) I. Давіденко, 2021

${ }^{1}$ Ідеться як про образ Гегеля-предтечі марксистської думки, так і про узвичаєні в радянському марксизмі підходи до Гегелевої філософії, що ігнорували обшир і глибину охоплюваних нею тематик. На моє переконання, здебільшого саме ці фактори понад чверть століття відвертали інтерес переважної більшості українських дослідників від Гегелевого вчення або спрямовували його в непродуктивне річище радянізованого гегелезнавства.

${ }^{2}$ Надалі ця книга називатиметься скорочено - Посібник

${ }^{3}$ Марина Бикова, професорка Університету Північної Кароліни, авторка і редакторка численних публікацій і збірок, присвячених німецькому ідеалізмові й філософії Гегеля. Зокрема, публікації Бикової, присвячені цим тематикам, можна зустріти в таких виданнях, як щорічник Міжнародного Гегелівського товариства «Hegel-Jahrbuch» [Bykova 2004; 2016], збірках [Bykova 2009; 2013; 2014]. Як редакторка, вона долучилася до роботи над [Bykova 2019; 2020a; 2020b]. Огляд видання [Bykova 2019] див.: [Давіденко 2020].

${ }^{4}$ Кеннет Вестфал, професор Босфорського університету в Стамбулі, автор і редактор численних публікацій, праць і збірок, присвячених, зокрема, модерній філософії та філософії Гегеля. Зокрема, Вестфал є автором праць [Westphal 1989; 2003; 2004; 2020a; 2020b]. Як редактор, він працював над виданнями [Westphal 1998; 2009; 2014]. 
Доречно розпочати наш огляд із місця збірки в загальному контексті проєктів видавництва. Palgrave Macmillan (Велика Британія) спеціалізується на академічній літературі з гуманітаристики та соціальних наук. Одним з найпотужніших проєктів цього видавництва в галузі філософії та історії філософії $є$ серія «Palgrave Handbooks in German Idealism», першою збіркою в якій став «Посібник з німецького ідеалізму» за ред. Метью Алтмана [Altman 2014]. Алтман, що став також і редактором усієї серії, визначає її специфіку так: «Будучи частиною цієї висхідної [growing] дискусії [щодо статусу німецького ідеалізму в сучасній філософії - I. Д.], посібники з німецького ідеалізму Palgrave покликані запропонувати огляди головних фігур і течій німецького ідеалізму з тією мірою широти та глибини висвітлення, що вирізняє їх 3-поміж інших антологій» [Bykova, Westphal 2020: v] ${ }^{5}$. Усі посібники серії складаються з матеріалів, спеціально написаних дослідниками, що представляють різні країни. Ці матеріали дозволяють людині, що не $\epsilon$ фахівцем з даної тематики, скласти найповніше враження про предмет збірки, фахівцеві ж - включитися в контекст актуальних наукових дискусій. «Посібник з Гегеля», що $€$ предметом нашого огляду, становить п'яту збірку серії.

Як зазначають редактори у вступі до збірки, підставою для створення Посібника $\epsilon$, попри комплексність цієї праці, зовсім не спроба виробити якесь остаточне бачення Гегелевої філософії та її майбутнього (р. l). За часів глобалізації багатьох дослідницьких напрямків у історико-філософській науці дедалі важливішим стає радше таке собі робоче загальне бачення предмету, що стало б контекстом для вузькоспеціалізованих досліджень. Власне, редакторам і авторам Посібника йдеться саме про те, щоб запропонувати таке бачення, описати конщептуальний каркас Гегелевої філософії в загальному (однак повсякчасно точному й обгрунтованому) нарисі через сукупність точкових досліджень (pp. vii-viii).

На відміну від численних вузькоспеціалізованих збірок, Посібник складається з 28 розділів, присвячених Гегелевій філософії в різних ії аспектах: становлення Гегеля як філософа, його філософської системи, рецепції Гегелевого вчення в історії та сьогоденні філософії. Структурно Посібник поділяється на вісім тематичних частин: перша присвячена інтелектуальному підгрунтю Гегелевої філософії, друга - «Феноменології духа», третя - «Науці логіки» та системі філософії, четверта - «Філософії природи», п’ята «Філософії духа», шоста - Гегелевій практичній і політичній філософії, сьома - Гегелевій філософії історії та історії філософії, восьма - гегельянству та пост-гегельянській думці, зокрема й критикам гегельянства.

Над матеріалами збірки працювали 24 фахових гегелезнавця, що представляють освітні й наукові інституції різних країн. Так, у роботі над збіркою взяли участь 10 представників академічних установ США (зокрема Майкл Баур, секретар Гегелевого товариства Америки, і Ардіс Б. Колінз, головний редактор «Сови Мінерви», міжнародного наукового журналу, що випускається згаданим товариством), 4 - Німеччини, 3 - Італії, по 2 - Австралії та Нідерландів, по 1 - Канади, Туреччини та Росії.

Саме такими є мета Посібника (напрацювання загальної візії Гегелевої філософіï) та спосіб іiі реалізації (точкові дослідження галузевих фахівців) (р. l). Така спрямованість тут важко не погодитися з Олегом Хомою [Хома 2019: 114] - робить подібні видання обов'язковим читанням для сучасних дослідників у відповідній галузі. Особливо ж значущими такі видання є при зародженні деяких галузевих дослідницьких тенденцій на

${ }^{5}$ Надалі посилання на це джерело подаються спрощено: зазначаємо номер сторінки після скорочення р. у круглих дужках, без прізвищ укладачів і року видання. 
локальному рівні (наприклад, в Україні), адже дозволяють у порівняно стислій формі ознайомитись із сьогоденням світових розвідок з відповідної теми (що, звісно ж, не применшує їхньої значущості для глобального дослідницького контексту).

Зрештою, як про різноманіття авторів розділів, так і про широту охоплення теми, якнайкраще свідчить зміст Посібника, який вважаємо необхідним навести тут повністю ${ }^{6}$ :

\section{Частина І. Інтелектуальне тло та філософський проект}

1. Марина Бикова, Гегель: його життя та шлях до філософії; 2. Майкл Баур, Визначаючи Гегеля: від трансиендентальної філософії до «Феноменології духа»; 3. Кенет Р. Вестфал, Кант, Гетель та історичність чистого розуму; 4. Джузеппе Варньє, Гетелева епістемологія.

\section{Частина ІІ. Феноменологія духа}

5. Ардіс Б. Колінз, Роль релігії в Гегелевому феноменологічному обтрунтуванні філософської науки; 6. Пірмін Штекелер-Вайтгофер, Абсолютний дух у перформативних само-стосунках осіб (self-relations of persons); Кенет Р. Вестфал, Індвивідуальність, Iндивідуалізм і наш людський zoоn politikon.

\section{Частина III. Наука логіки та система філософії}

8. Анжеліка Нуццо, Метод в Гетелевій діалектико-спекулятивній логіиі; 9. Джон В. Бербрідж, Aufhebung; 10. Генрі М. Саусгейт, Свобода як належність: захист гетельянського холізму.

\section{Частина IV. Філософія природи}

11. Міхаель Вольф, Рівні реальності чи розвитку? Гегелева Realphilosophie ma фiлософія наук; 12. Кенет Р. Вестфал, Кавзальність, природні системи та Гетелів органіцизм; 13. Чінціа Ферріні, Гелелева філософія природного та людського просторів.

\section{Частина V. Філософія духа}

14. Італо Теста, Воплочена когнічія, звичка та природна діяльність; 15. Аллегра де Лаурентіс, Чутливість (Sentience) та почуття в антропологї; 16. Маркус Габріель, Iнтуїиія, репрезентація та мислення: Гетелева психологія та проблема розташування; 17. Ален Спейт, Гетель про поезію, прозу та походження мистецтва; 18. Роберт Вільямс, Гетелеве перетворення теологічних доказів.

\section{Частина VI. Практична та політичні філософія}

19. Крістофер Л. Йоманс, Логіка та соціальна теорія: Гетель про конщептуальну значущість політичних змін; 20. Крістіан Крайнен, Sittlichkeit i актуальність свободи: про Канта та Гетеля; 21. Іван Болдирєв, Спекулятивний інституиіоналізм: Гетелів спадок для будь-якої політичної економії, що зможе постати як наука; 22. Марина Ф. Бикова, Гетелева філософія Bildung.

Частина VII. Філософія світової історії та історія філософії

23. Андреас Арндт, Гетелева філософія світової історії; 24. Саймон Люмсден, Свобода та логіка історї; 25. Неллі В. Мотрошилова, Історія філософії в Гегелевій системі.

Частина VIII. Гегельянство та пост-гегельянська думка

26. Пол Редінг, Гетель і сучасна аналітична метафізика; 27. Вілем де Вріс, Гегелів прагматизм; 28. Пол Редінг, «Пітсбурзьке» нео-гетельянство Роберта Брендома та Джсна Макдавела.

${ }^{6}$ Автор висловлює щиру подяку Іванові Іващенку за цінні поради щодо перекладу деяких понять і поняттєвих конструкцій, ужитих авторами Посібника. 
Матеріали Посібника мають переважно історико-філософський характер: історія постання, тексти, концепти та поняття Гегелевого вчення розглядаються з незмінною увагою до контексту їхньої появи, ролі в проєкті систематичної філософії, текстології та традиції їх інтерпретації. Підхід авторів Посібника до Гегелевої філософії, звісно, варіює залежно від особливостей їхньої філософської позиції (зокрема зумовленої приналежністю до певного локального інтелектуального центру). Але ці природні індивідуальні особливості авторів не роблять їх менш відкритими до світових дослідницьких тенденцій. Важливою рисою більшості матеріалів Посібника $є$ доповнення історико-філософського розгляду контекстом сучасних філософських дискусій. Яскравим прикладом такої контекстуалізації є стаття професора Пармського університету Італо Тести Воплочена когнічія, звичка та природна діяльність, де автор, принагідно до сучасних проблем philosophy of mind, когнітивних наук і теорії дії (зокрема, дискусій щодо феномену втіленості свідомості), досліджує представлене в Гегелевій теорії втілення (Verleiblichung) поняття звички (Gewohnheit). Отже, хоча Посібник і складається насамперед з історикофілософських досліджень, останні звертаються до сучасних дискусій, послідовно актуалізуючи філософію Гегеля.

Загальною ж настановою Посібника щодо розгляду власне Гегелевого вчення, на якій особливо важливо наголосити в українському контексті, є дотримання системного підходу (p. xlviii). Зрештою, це й не дивно, адже один з редакторів Посібника, Марина Бикова, є знаним прибічником цього підходу [див.: Bykova 2019: 3]. Системний підхід до вивчення Гегелевої філософії передбачає ії розгляд як структурно та континуально цілого та, отже, заперечує можливість (принаймні коли йтиметься про історико-філософське дослідження) розгляду текстів, понять та ідей Гегелевого вчення поза всією системою, функціональними частинами якої вони є. Чинність цього підходу для Посібника підтверджується не лише самими дослідженнями та вже згаданою настановою на цүiлісне бачення Гегелевої філософії, а й окремо наголошуваною та винесеною в додаток зведеною схемою Гегелевої системи філософії в працях та лекційних курсах (рp.. 578-579), що дає якнайкраще уявлення про ціле Гегелевого вчення, грунтуючись на конкретиці текстів.

Коли вже було згадано один з додатків до Посібника, варто відзначити високу академічну й видавничу культуру всієї збірки, яка виражається насамперед у ії оформленні. Посібник є академічним виданням, отже - має якісно оформлені примітки й посилання; зручну й повну бібліографію, супутню кожному розділу; два змістовні додатки, присвячені хронології життя Гегеля та системі його філософії; редакторські висновки, що узагальнюють результати досліджень збірки через формулювання перспективних тематик подальших досліджень; іменний та предметний покажчики. Безперечно, такий рівень культури наукових публікацій - плід дуже тривалих практик. Саме такі видання, якщо ми, наприклад, матимемо намір змінити на краще ситуацію з гегелезнавчими дослідженнями в Україні, можуть слугувати дороговказом.

Насамкінець варто констатувати: навіть попри стрімкий розвиток гегелезнавства, подібні масштабні збірки лишаються вельми нечастим явищем, порівняно з величезною кількістю вузько-спеціалізованих збірок. Серед подібних найновіших комплексних видань, що претендують на одночасне охоплення багатьох тематик і контекстів Гегелевої філософії, можемо згадати «Посібник з Гегеля» за редакцією Діна Мояра [Moyar 2017] і «Довідник з Гегеля та філософії XIX століття» за редакцією Фредерика Ч. Бейзера [Baser 2008]. Якщо вдатись до порівняння цих збірок, оксфордський «Посібник з Гегеля» $є$ найобсяжнішим, адже містить 34 розділи проти 28 Посібника та 15 «Довідника 
3 Гегеля та філософії XIX століття». Посібник, натомість, має значно ширшу та тематизованішу структуру, ніж інші дві щойно згадані збірки, а тому й охоплює, хоч і не так детально, як оксфордська, ширше тематичне коло. Зрештою, на наше переконання, протиставлення цих збірок позбавлене сенсу, адже вони є порівняно новим жанром академічної літератури, та нечасто повторюються в тематиках дослідницьких матеріалів. До того ж, завжди мінливим є й контекст історико-філософського дослідження, адже за часів інтенсифікації академічних досліджень завжди змінюється те поле актуальності, у контексті якого ці дослідження відбуваються. Таким чином, на підставі порівняльного огляду цих видань можна стверджувати, що вони, по-перше, наочно ілюструють розвиток у гегелезнавстві, i, по-друге, є взаємодоповнювальними матеріалами для фахових досліджень Гегелевої філософії. Кожна з цих збірок по-своєму увиразнює ті чи інші аспекти сучасної дослідницької візії Гегелевого вчення (якщо, звісно, про неї можна говорити в однині).

Варто також сказати, що Посібник є досить типовим для сучасної академічної науки виданням: вельми широкий міжнародний перелік авторів, редакторство знаних фахівців, увага як до історико-філософського характеру дослідження, так і до сучасних дискусій у філософії, спрямованість водночас і на науковий, і на освітній вжиток, зразкове оформлення: усе це, на нашу думку, робить Посібник обов'язковим джерелом для сучасних українських дослідників Гегелевої філософії й дуже бажаним для ширшого дослідницького загалу. Слід особливо наголосити й на тому, що дуже плідним було б використання Посібника при викладанні історії німецького ідеалізму загалом та Гегелевої філософії зокрема. Адже те поєднання дослідження й актуалізації, яке зустрічаємо в збірці, може як зайвий раз вказати вітчизняному студентові зразки сучасного філософського дослідження, так і заохотити до вивчення саме Гегелевої філософії. Безперечно, у межах однієї збірки майже неможливо повною мірою досягти поставленої редакторами мети зі створення цілісного історико-філософського бачення Гегелевої філософії. Але, як виглядає, справа не в тому, щоби повністю й детально викласти таке бачення, а радше в тому, щоб окреслити його в головних і найактуальніших моментах. Зрештою, завдяки як великій кількості посилань на фундаментальні дослідження авторів збірки та вже визнаних метрів сучасного гегелезнавства (як-от Роберт Піпін чи Роберт Брендом), так і спрямованості на актуальні тематики, Посібнику, зрештою, вдається стати тим, чим він прагне бути: загальним, але точним і обгрунтованим в усіх своїх пунктах ескізом концептуального каркасу сучасного гегелезнавства. Враховуючи особливості нашого локального контексту, нам варто якомога ретельніше знайомитися з подібними виданнями й орієнтуватися на них. Тоді, можливо, уже в перспективі найближчих десятиліть філософська спільнота України не вважатиме питання «чи потрібен нам (такий) Гегель ${ }^{7} \gg$ актуальним.

7 Тут автор перефразовує назву статті Віктора Козловського Чи потрібен нам Гегель? (нотатки читача до українського перекладу «Феноменології духу») [Козловський 2020]. У цій статті - на прикладі перевидання українського перекладу Гегелевої праці - проблематизується недбале ставлення до підготовки, коментування й оформлення академічних видань, великою мірою властиве, на жаль, нашій академічній і видавничій практиці. Так само автор має на увазі те, що, завдяки ознайомленню з виданнями на кшталт Посібника, ми побачимо справжні можливості актуалізації філософських вчень минулого в межах історико-філософських досліджень, що сприятиме більшій увазі й фахового середовища, і суспільства до таких досліджень. 


\section{СПИСОК ЛІТЕРАТУРИ}

Давіденко, I. (2020). Реактуалізуючи Гегеля: поступ сучасного гегелезнавства. Bykova, M. et al. (2019). Hegel's Philosophy of Spirit: a critical guide. Cambridge: Cambridge UP. Sententiae, 39(1), 226-231. https://doi.org/10.31649/sent39.01.226

Козловський, В. (2020). Чи потрібен нам Гегель? (нотатки читача до українського перекладу «Феноменології духу»). Наукові записки НаУКМА. Філософія та релігієзнавство, 5, 90-102. https://doi.org/10.18523/2617-1678.2020.5.90-102

Хома, О. (2019). Сучасне глобальне декартознавство. Nadler, S. et al (2019). The Oxford Handbook of Descartes and Cartesianism. Oxford: Oxford UP. Sententiae, 38(2), 112-115. https://doi.org/10.22240/sent38.02.112

Altman, M. (Ed.). (2014). The Palgrave handbook of German idealism. Basingstoke: Palgrave Macmillan. https://doi.org/10.1057/9781137334756

Baser, F. (Ed.). (2008). The Cambridge companion to Hegel and nineteenth-century philosophy. Cambridge: Cambridge University Press. https://doi.org/10.1017/CCOL9780521831673

Bykova, M. (2004). Zu Hegels Subjektivitätstheorie aus der Perspektive der systematischen Beziehungen zwischen Logik und Realphilosophie. Hegel-Jahrbuch, (6), 253-259. https://doi.org/10.1524/hgjb.2004.6.jg.253

Bykova, M. (2009). Spirit and Concrete Subjectivity in Hegel's Phenomenology of Spirit. In K. Westphal (Ed.), The Blackwell Guide to Hegel's Phenomenology of Spirit (pp. 265-295). Oxford : Wiley-Blackwell. https://doi.org/10.1002/9781444306224.ch13

Bykova, M. (2013). Thinking and Knowing. In A. de Laurentis, \& J. Edwards (Eds.), Bloomsbury Companion to Hegel (pp. 225-230). London: Continuum.

Bykova, M. (2014). Fichte: His Life and Philosophical Calling. In M. Altman (Ed.), The Palgrave Handbook of German Idealism (pp. 267-285). London: Palgrave Macmillan.

Bykova, M. (2016). On Thinking and Knowing. Hegel's Response to Kant's Epistemological Challenge. Hegel-Jahrbuch, (1), 201-206. https://doi.org/10.1515/hgjb-2016-0135

Bykova, M. (Ed.). (2019). Hegel's Philosophy of spirit: a critical guide. Cambridge: Cambridge University Press. https://doi.org/10.1017/9781108164184

Bykova, M. (Ed.). (2020a). The Bloomsbury Handbook of Fichte. London: Bloomsbury Academic. https://doi.org/10.5040/9781350036642

Bykova, M. (Ed.). (2020b). The German Idealism Reader: Ideas, Responses and Legacy. London: Bloomsbury Academic.

Bykova, M., Westphal, K. et al. (2020). The Palgrave Hegel handbook. Basingstoke: Palgrave Macmillan. https://doi.org/10.1007/978-3-030-26597-7

Moyar, D. (Ed). (2017). The Oxford Handbook of Hegel. New York: Oxford UP. https://doi.org/10.1093/oxfordhb/9780199355228.001.0001

Westphal, K. (1989). Hegel's Epistemological Realism: A Study of the Aim and Method of Hegel's Phenomenology of Spirit. Boston: Kluwer Academic Publishers. https://doi.org/10.1007/97894-009-2342-3

Westphal, K. (2003). Hegel's Epistemology: A Philosophical Introduction to the Phenomenology of Spirit. Indianapolis, IN : Hackett.

Westphal, K. (2004). Kant's Transcendental Proof of Realism. Cambridge: Cambridge UP. https://doi.org/10.1017/CBO9780511584497

Westphal, K. (2020a). Hegel's Civic Republicanism: Integrating Natural Law with Kant's Moral Constructivism. London: Routledge. https://doi.org/10.4324/9780429343483

Westphal, K. (2020b). Kant's Critical Epistemology: Why Epistemology Must Consider Judgment First. New York : Routledge. https://doi.org/10.4324/9781003082361

Westphal, K. (Ed.). (1998). Pragmatism, Reason, and Norms: A Realistic Assessment. New York: Fordham University Press.

Westphal, K. (Ed.). (2009). The Blackwell Guide to Hegel's Phenomenology of Spirit. Oxford: Wiley-Blackwell. https://doi.org/10.1002/9781444306224

Westphal, K. (Ed.). (2014). Realism, Science, and Pragmatism. New York: Routledge. https://doi.org/10.4324/9781315779515

Одержано 23.10.2020 


\section{REFERENCES}

Altman, M. (Ed.). (2014). The Palgrave handbook of German idealism. Basingstoke: Palgrave Macmillan. https://doi.org/10.1057/9781137334756

Baser, F. (Ed.). (2008). The Cambridge companion to Hegel and nineteenth-century philosophy. Cambridge: Cambridge University Press. https://doi.org/10.1017/CCOL9780521831673

Bykova, M. (2004). Zu Hegels Subjektivitätstheorie aus der Perspektive der systematischen Beziehungen zwischen Logik und Realphilosophie. Hegel-Jahrbuch, (6), 253-259. https://doi.org/10.1524/hgjb.2004.6.jg.253

Bykova, M. (2009). Spirit and Concrete Subjectivity in Hegel's Phenomenology of Spirit. In K. Westphal (Ed.), The Blackwell Guide to Hegel's Phenomenology of Spirit (pp. 265-295). Oxford : Wiley-Blackwell. https://doi.org/10.1002/9781444306224.ch13

Bykova, M. (2013). Thinking and Knowing. In A. de Laurentis, \& J. Edwards (Eds.), Bloomsbury Companion to Hegel (pp. 225-230). London: Continuum.

Bykova, M. (2014). Fichte: His Life and Philosophical Calling. In M. Altman (Ed.), The Palgrave Handbook of German Idealism (pp. 267-285). London: Palgrave Macmillan.

Bykova, M. (2016). On Thinking and Knowing. Hegel's Response to Kant's Epistemological Challenge. Hegel-Jahrbuch, (1), 201-206. https://doi.org/10.1515/hgjb-2016-0135

Bykova, M. (Ed.). (2019). Hegel's Philosophy of spirit: a critical guide. Cambridge: Cambridge University Press. https://doi.org/10.1017/9781108164184

Bykova, M. (Ed.). (2020a). The Bloomsbury Handbook of Fichte. London: Bloomsbury Academic. https://doi.org/10.5040/9781350036642

Bykova, M. (Ed.). (2020b). The German Idealism Reader: Ideas, Responses and Legacy. London: Bloomsbury Academic.

Bykova, M., Westphal, K. et al. (2020). The Palgrave Hegel handbook. Basingstoke: Palgrave Macmillan. https://doi.org/10.1007/978-3-030-26597-7

Davidenko, I. (2020). Reactualizing Hegel: the progress of modern Hegelian studies. Bykova, M. et al. (2019). Hegel's Philosophy of Spirit: a critical guide. Cambridge: Cambridge UP. [In Ukrainian]. Sententiae, 39(1), 226-231. https://doi.org/10.31649/sent39.01.226

Khoma, O. (2019). Contemporary global Descartes studies. Nadler, S. et al (2019). The Oxford Handbook of Descartes and Cartesianism. Oxford: Oxford UP. [In Ukrainian]. Sententiae, 38(2), 112-115. https://doi.org/10.22240/sent38.02.112

Kozlovskyi V. (2020). Do we need Hegel? (reader's notes to the ukrainian translation of "The Phenomenology of Spirit”. [In Ukrainian]. NaUKMA Research Papers in Philosophy and Religious Studies, 5, 90-102. https://doi.org/10.18523/2617-1678.2020.5.90-102

Moyar, D. (Ed). (2017). The Oxford Handbook of Hegel. New York: Oxford UP. https://doi.org/10.1093/oxfordhb/9780199355228.001.0001

Westphal, K. (1989). Hegel's Epistemological Realism: A Study of the Aim and Method of Hegel's Phenomenology of Spirit. Boston: Kluwer Academic Publishers. https://doi.org/10.1007/97894-009-2342-3

Westphal, K. (2003). Hegel's Epistemology: A Philosophical Introduction to the Phenomenology of Spirit. Indianapolis, IN : Hackett.

Westphal, K. (2004). Kant's Transcendental Proof of Realism. Cambridge: Cambridge UP. https://doi.org/10.1017/CBO9780511584497

Westphal, K. (2020a). Hegel's Civic Republicanism: Integrating Natural Law with Kant's Moral Constructivism. London: Routledge. https://doi.org/10.4324/9780429343483

Westphal, K. (2020b). Kant's Critical Epistemology: Why Epistemology Must Consider Judgment First. New York : Routledge. https://doi.org/10.4324/9781003082361

Westphal, K. (Ed.). (1998). Pragmatism, Reason, and Norms: A Realistic Assessment. New York: Fordham University Press.

Westphal, K. (Ed.). (2009). The Blackwell Guide to Hegel's Phenomenology of Spirit. Oxford: Wiley-Blackwell. https://doi.org/10.1002/9781444306224

Westphal, K. (Ed.). (2014). Realism, Science, and Pragmatism. New York: Routledge. https://doi.org/10.4324/9781315779515

Received 23.10.2020 


\section{Illia Davidenko}

Trends in modern Hegelean studies. Bykova, M., Westphal, K., et al. (2020). The Palgrave Hegel handbook. Basingstoke: Palgrave Macmillan.

Review of Bykova, M., Westphal, K., et al. (2020). The Palgrave Hegel handbook. Basingstoke: Palgrave Macmillan.

\section{Ілля Давіденко}

Тенденції сучасного гегелезнавства. Bykova, M., Westphal, K., et al. (2020). The Palgrave Hegel handbook. Basingstoke: Palgrave Macmillan.

Огляд книги Bykova, M., Westphal, K., et al. (2020). The Palgrave Hegel handbook. Basingstoke: Palgrave Macmillan.

Illia Davidenko, master student, Faculty of Philosophy, Taras Shevchenko National University of Kyiv (Ukraine).

Ілля Давіденко, магістрант філософського факультету Київського начіонального університету імені Тараса Шевченка.

e-mail: illia.davidenko@gmail.com 